\title{
Refusing to Negotiate: Analyzing the Legality and Practicality of a Piracy Ransom Ban
}

\author{
Yvonne M. Dutton ${ }^{\dagger} \&$ Jon Bellish ${ }^{\dagger \dagger}$
}

Introduction

I. The Modern Maritime Piracy Problem ............. 303

A. The Rise and Continued Threat of Somali Piracy ....... 303

B. The Somali Piracy-For-Ransom Business Model........ 305

II. The Ethical Dilemma of Banning Ransom Payments ..... 307

A. Countries' Ransom Policies ...................... 309

B. Banning Piracy Ransoms: Arguments For and Against .. 312

III. Analyzing the Legality of a Piracy Ransom Ban ......... 315

A. Kidnapping, Extortion, and Bribery .............. 316

B. Financing Terrorism ........................ 319

IV. Analyzing the Practicality of a Piracy Ransom Ban ...... 322

Conclusion ..................................... 328

\section{Introduction}

In 2009, retired engineer Paul Chandler and his economist wife, Rachel, set off in their 38-foot yacht for a sailing trip around the world. ${ }^{1}$ The trip did not go as planned. On October 23, 2009, while the couple was en route from the Seychelles to Tanzania, they set off their emergency beacon. $^{2}$ By October 28 , it was clear that they had been captured by pirates. ${ }^{3}$ The pirates threatened to use the Chandlers as insurance to derail a rescue attempt for another set of hostages. ${ }^{4}$ The evidence, though, showed that

$\dagger$ Associate Professor, Indiana University Robert H. McKinney School of Law. Yvonne Dutton gratefully acknowledges the support she received for this project from an Indiana University New Frontiers Exploratory Travel Grant.

$\dagger^{\dagger}$ Project Officer, Oceans Beyond Piracy; Nanda Center Fellow, University of Denver Sturm College of Law.

1. Brian Flynn, John Coles, \& Neil Syson, Brits' yacht seen on way to port, Sun (Oct. 28, 2009), http://www.hiiraan.com/news4/2009/Oct/12604/brits_yacht_seen_on_way _to_port.aspx; Xan Rice \& Sam Jones, Somali pirates claim to have seized British couple's yacht, Guardian (Oct. 27, 2009), http://www.theguardian.com/world/2009/oct/27/ somali-pirates-british-yacht; Caroline Davies, Sam Jones, \& Xan Rice, Tunbridge Wells couple on dream voyage seized by pirates, GuARDIAN (Oct. 27, 2009), http://www.guardian .co.uk/world/2009/oct/27/pirates-seize-turnbridge-wells-couple.

2. Rice \& Jones, supra note 1.

3. Flynn, Coles \& Syson, supra note 1.

4. Caroline Davies, British couple seized as insurance, say pirates, Guardian (Oct. 28, 2009), http://www.guardian.co.uk/world/2009/oct/28/britons-seized-by-somali-pirates [hereinafter British Couple Seized].

47 Cornell Int'L L.J. 299 (2014) 
what the pirates really wanted was a ransom payment. ${ }^{5}$

The pirates' initial demand of $£ 4.2$ million was not even a day old before Her Majesty's Government stated its unequivocal position: "The government will not make any substantive concessions to hostage-takers, including the payment of ransoms." ${ }^{-6}$ The UK government's position was particularly problematic for the Chandlers because the latter had no insurance, and had used the vast majority of their funds to finance their trip. ${ }^{7}$ The next thirteen months were marked by the Chandlers' repeated pleas for assistance and reports of their physical and emotional abuse. ${ }^{8}$ The following statement from Paul Chandler on a tape released in January 2010 is representative of the couple's calls for help, especially as their situation became increasingly dire:

I just want to say please to my government get me and my wife out of here. We are innocent, we have done no wrong. We have no money and we can't pay a ransom. We just need the government to help, anyone who can help us out of here. Day after day and this is 98 days of solitary confinement, no exercise. I don't know what to do. Will somebody please help? The government or somebody else? ${ }^{9}$

Although the UK government never wavered in its "no concessions" policy, ${ }^{10}$ the Chandlers' relatives managed to assemble enough money to satisfy the pirates who were holding them hostage. ${ }^{11}$ In November 2010, after the pirates received a ransom of around $£ 62,000$, the couple was sent home. ${ }^{12}$ In the words of Paul Chandler, they were "rather skinny and bony but . . . fine."13

The Chandlers are just two amongst thousands of innocent victims

5. Flynn, Coles \& Syson, supra note 1 .

6. Sam Jones, Somali pirates demand $\$ 7 \mathrm{~m}$ to release British hostages, Guardian (Oct. 30, 2009), http://www.guardian.co.uk/world/2009/oct/30/somalian-pirates-yachtcouple-hostages.

7. Xan Rice, The Chandlers' release: How the deal was done, GuARDian (Nov. 14, 2010), http://www.guardian.co.uk/world/2010/nov/14/paul-chandler-rachel-chandlerrelease-deal; British couple seized, supra note 4.

8. The Chandlers' release: How the deal was done, supra note 7; British couple held by pirates filmed appealing for government help, Guardian (Jan. 31, 2010), http://www.the guardian.com/world/2010/jan/31/paul-rachel-chandler-pirate-captive [hereinafter British couple appealing for government help].

9. British couple appealing for government help, supra note 8.

10. David Batty, Kidnapped Britons believe Somali pirates will kill them, GUARDIAN (Jan. 21, 2010), http://www.guardian.co.uk/world/2010/jan/21/britons-held-by-soma li-pirates; British couple appealing for government help, supra note 8; Virginia Wheeler, Hostage Brits' plea to the PM, Sun (May 27, 2010), http://www.thesun.co.uk/sol/home page/news/2989458/Hostage-Brits-plea-to-David-Cameron.html; Haroon Siddique, Paul and Rachel Chandler appeal to David Cameron to secure their release, GuARDIAN (May 26, 2010), http://www.guardian.co.uk/world/2010/may/26/paul-rachel-chandler-hostagepiracy.

11. See The Chandlers' release: How the deal was done, supra note 7.

12. Neil Syson \& Alex West, Brit pair's hostage hell over, Sun (Jan. 12, 2011), http:// www.thesun.co.uk/sol/homepage/news/3227722/Brit-pairs-hostage-hell-over.html

13. Somali pirates free UK couple Paul and Rachel Chandler, BBC (Nov. 14, 2010), http://www.bbc.co.uk/news/uk-11752027. 
who have suffered at the hands of Somali pirates since the mid-2000s. ${ }^{14} \mathrm{~A}$ recent study by the World Bank reports that "[a]s many as 3,741 crewmembers of 125 different nationalities have fallen prey to [Somali] pirates, with detention periods of as long as 1,178 days." 15 Between 2010 and 2012 alone, Somali pirates hijacked over ninety vessels and received $\$ 367.37$ million in ransom payments. ${ }^{16}$ As of December 2012, Somali pirates were holding more than 100 crewmembers of different nationalities captive. ${ }^{17}$

Despite the international community's anti-piracy measures, the Chandlers and many others have fallen victim to Somali pirates. Since 2008, navies have been patrolling the pirate-infested waters off the Somali coast, and since mid-2011, a large percentage of ships have been employing private armed guards to protect them against pirate attacks. ${ }^{18}$ These and other measures have had some success at keeping seafarers safe. ${ }^{19}$ Those who have participated in the naval counter-piracy patrols, however, warn against complacency. ${ }^{20}$ As one U.S. admiral has explained, pirates are in the business of making money, and they have found, and will continue to find, ways to overcome the defensive measures that are implemented to prevent successful hijackings. ${ }^{21}$

Indeed, there is no reason to believe that pirates will simply abandon the illegal activities that have enabled them to reap huge monetary rewards. ${ }^{22}$ Somali pirates will continue to hijack ships in exchange for ransom payments because the payments have only been growing in recent years. ${ }^{23}$ The average ransom has "increased sevenfold in the last five years" from about $\$ 600,000$ in 2007 to about $\$ 5$ million in 2011. ${ }^{24}$ Although exact numbers are not known, estimates suggest that individual pirate crewmembers or guards can earn between $\$ 10,000$ and $\$ 15,000$ for partic-

14. The World Bank Regional Vice-Presidency for Africa, The Pirates of Somalia: Ending the Threat, Rebuilding a Nation, at xxi-xxii (2013), available at http://siteresources.worldbank.org/INTAFRICA/Resources/pirates-of-somalia-main-report-web.pdf [hereinafter 2013 WORLD BANK REPORT].

15. Id. at xxii.

16. Jonathan Bellish et. al., The Economic Cost of Somali Piracy 2012, at 11 (2012), available at http://oceansbeyondpiracy.org/sites/default/files/attachments/ View\%20Full\%20Report_l.pdf [hereinafter ECOP 2012].

17. Int'l Chamber of Commerce Int'l Maritime Bureau, Piracy and Armed Robbery Against Ships 20 (2013), available at http://www.crimson.eu.com/assets/2012_Annual_ IMB_Piracy_Report.pdf [hereinafter ICC-IMB 2012 REPORT].

18. See infra notes 42-43, 46 and accompanying text.

19. See e.g., ICC-IMB 2012 RePORT, supra note 17, at 5-6.

20. Admiral warns against withdrawing naval support on piracy, Maritime SECURITY INT'L (Oct. 24, 2012), http://www.maritimesecurityinternational.net/readnews.php?ide $=87$.

21. Id.

22. 2013 World BAnk Report, supra note 14, at 89 (detailing how most Somali hijackings are organized by an instigator who gathers or provides funding for the attack and identifies a pirate commander to organize the attack; those who finance the attack are thereafter entitled to a portion of any ransom collected).

23. Foreign Affairs Committee, Piracy off the Coast of Somalia, 2010-2012, H.C. 1318 , at 55 (U.K.).

24. Id. 
ipating in a successful attack, ${ }^{25}$ and perhaps more than $\$ 50,000$ in a year. ${ }^{26}$ These sums are huge in Somalia, a country where the youth unemployment rate is around $67 \%,{ }^{27}$ and the median income is approximately $\$ 600$ per year. $^{28}$

Concerns that ransom payments play a large role in encouraging and sustaining maritime piracy have prompted some, including British Prime Minister David Cameron, to suggest that banning ransom payments in their entirety may be necessary to end the threat. ${ }^{29}$ If pirates attack ships in the hope of obtaining a lucrative ransom payoff, then taking away the possibility of a ransom payment should eliminate the incentive to engage in piracy, as well as strip pirates of the opportunity to obtain the funds necessary to finance future illegal activities. This deterrence argument is what governments with "no concessions" policies point to when they refuse to negotiate with hostage-takers. ${ }^{30}$ Some governments, like those of the United States and the United Kingdom, cite this deterrence argument to discourage their private citizens and companies from acceding to ransom demands. ${ }^{31}$

However, as the Chandlers' story illustrates, refusing to negotiate with hostage-takers also puts innocent lives at risk. ${ }^{32}$ This is the contrasting point that ship owners and their industry representatives make in response to any suggestions that governments should ban ransom payments. ${ }^{33}$ Ship owners have thus far made sure that they can accede to pirates' ransom demands by purchasing kidnap and ransom insurance. ${ }^{34}$

This Article is sympathetic to both the arguments in favor of and against a piracy ransom ban. At the same time, we suggest that additional analysis is warranted before anyone concludes that a piracy ransom ban would offer a promising tool for solving the problem of maritime piracy. This Article undertakes that additional analysis by examining (1) the legal-

25. 2013 World Bank Report, supra notel4, at 112.

26. Geopolicity, The Economics of Piracy: Pirate Ransoms \& Livelihoods off the COASt of Somalia 12 (2011), available at http://www.geopolicity.com/upload/content/ pub_1305229189_regular.pdf.

27. United Nations Development Programme Somalia, Somalia Human Development Report 2012: Empowering Youth for Peace and Development, at xix (2012), http:// www.undp.org/content/dam/undp/library/corporate/HDR/Arab\%20States/HDR-Soma lia-2012-E.pdf.

28. See Christine Mungal, Somalia: Total Cost of Piracy Menace Leapfrogs Tanzania's Annual Budget, AllAfrica (May 11, 2011), http://allafrica.com/stories/201105111061 .html.

29. Nick Hopkins, Judith Tebbutt case puts spotlight on government's ransom policy, GuARDian (Mar. 21, 2012), http://www.guardian.co.uk/uk/2012/mar/21/judith-teb butt-spotlight-ransom-policy (detailing that British Prime Minister David Cameron has called for the creation of a task force on ransoms whose goal should be to end the practice of making ransom payments). See also discussion infra at notes 111-112.

30. See infra notes 87-95 and accompanying text.

31. See infra note 109 and accompanying text.

32. See supra notes 1-13 and accompanying text.

33. See Richard Neylon, Calls to ban ransom payments are misguided, LloYD's LisT (Oct. 31, 2011), http://www.lloydslist.com/ll/sector/ship-operations/article383161.ece.

34. See infra.notes 73-76 and accompanying text. 
ity of a ban from a criminal law standpoint on retributive theories about punishment and (2) the practicality of a ban given the international context in which the potential ban would have to apply.

We agree on the need to find a solution to the problem of maritime piracy and the piracy ransoms that help fuel the illegal activities that put lives at risk. We conclude, however, that a piracy ransom ban would likely be inconsistent with the retributive principles of criminal law, since it would punish innocent victims who pay ransoms under duress. We further suggest that even if there are good reasons, in theory, to criminalize ransom payments, banning piracy ransoms would be impractical from an international law standpoint since any such ban would pose collective action problems. In short, absent the unlikely universal ban, a piracy ransom ban, supported only by select countries, is unlikely to prove an effective deterrent to maritime piracy.

We proceed by briefly describing the modern maritime piracy problem and the piracy-for-ransom business model. After discussing the ethical dilemma posed generally by ransom bans, and some of the arguments for and against a piracy ransom ban, we then turn to analyzing the legality and practicality of a potential piracy ransom ban as a solution to the modern maritime piracy problem.

\section{The Modern Maritime Piracy Problem}

\section{A. The Rise and Continued Threat of Somali Piracy}

Around the end of the nineteenth century, most thought that the age of maritime piracy had ended. ${ }^{35}$ Unfortunately, that prediction proved premature. Around 2005, Somali pirates began launching attacks on vessels travelling off the Somali coast, hijacking ships and only releasing the ship and cargo upon the receipt of hefty ransom payments. ${ }^{36}$

Somali piracy reached its peak in 2010, with attacks spreading well off the coastline into the Indian Ocean and to the west coast of the Indian subcontinent. ${ }^{37}$ That year, Somali Pirates were responsible for 139 reported attempted hijackings, 49 of which were successful. ${ }^{38}$ The pirates reaped huge rewards for their illegal activities, receiving a total of $\$ 238$

35. Philip Gosse, The History of Piracy 297-98 (1932) ("It is likely that the disappearance [of pirates] is permanent.").

36. Int'l Chamber of Commerce Int'l Maritime Bureau, Piracy and Armed Robbery Against Ships Annual Report 16 (2006), available at http://www.le-havre.vessels-infrance.net/fichiersdoc/2005_ICC_Piracy_annual_report.pdf [hereinafter ICC-IMB 2005 REPORT].

37. See Anna Bowden et al., The Economic Cost of Somali Piracy 2011, at 8 (2012), available at http://oceansbeyondpiracy.org/sites/default/files/economic_cost_of _piracy_2011.pdf [hereinafter ECOP 2011].

38. Int'l Chamber of Commerce Int'l Maritime Bureau, Piracy and Armed Robbery Against Ships Annual Report 8 (2011), available at http://www.steamshipmutual.com/ Downloads/Piracy/IMBPiracyReport2010.pdf [hereinafter ICC-IMB 2010 REPORT]. 
million in exchange for releasing the crews and cargo of 44 ships. ${ }^{39}$ By 2010, maritime piracy off the coast of Somalia was truly a global menace, imposing a cost upwards of $\$ 7$ billion per year on those directly involved in combating piracy, ${ }^{40}$ and adding an estimated $\$ 18$ billion in total cost to the global economy. ${ }^{41}$

In fact, Somali pirate attacks reached that 2010 peak despite the international community's and individual ship owners' anti-piracy efforts. ${ }^{42}$ For example, since 2008 (and continuing through 2013), the world's navies have been escorting ships travelling off the Horn of Africa, patrolling the Indian Ocean to ward off attacks, and responding to reported attacks-at a cost of around $\$ 2$ billion per year. ${ }^{43}$ The shipping industry has also expended great efforts and sums in order to suppress piracy. ${ }^{44}$ At a cost of billions of dollars per year, ships have steamed at faster-than-optimal speeds through the Indian Ocean, re-routed to avoid vulnerability, and installed ship-hardening measures such as razor wire and safe rooms. ${ }^{45}$ When pirate attacks only continued to rise, however, by mid-2011, states began allowing their ship owners to hire private armed guards to protect them. ${ }^{46}$ Although anecdotal evidence suggests that the use of private guards has been very effective at preventing successful pirate attacks, ${ }^{47}$ the use of private guards remains controversial due to legal ambiguities and a perceived lack of regulatory oversight. ${ }^{48}$ The private maritime security industry barely existed before the rise of Somalia based piracy. ${ }^{49}$ Yet by 2012, more than 140 private security firms were operating in the Indian Ocean, ${ }^{50}$ costing ship owners and operators between $\$ 1.15$ and $\$ 1.53$ billion. ${ }^{51}$

Some evidence indicates that these various tactics are working: the number of Somali pirate attacks has been declining since the end of 2011.52 However, as cautioned by many of those involved in the fight

39. Anna Bowden et al., The Economic Costs of Maritime Piracy 10 (2010), available at https://www.cimicweb.org/cmo/Piracy/Documents/Economics\%20of\%20Piracy/ Cost $\% 20$ of\%20Piracy\%20Final\%20Report.pdf [hereinafter ECOP 2010].

40. Id. at 25.

41. 2013 WORLD BANK REPORT supra note 14, at 25. http://siteresources.worldbank .org/INTAFRICA/Resources/pirates-of-somalia-main-report-web.pdf.

42. ECOP 2010, supra note 39, at 14-16 (describing anti-piracy measures taken by naval forces and ship owners).

43. Id. at 15-16. As of 2011,20 states have contributed to the effort to combat piracy by prosecuting and imprisoning the pirates captured by their naval forces. ECOP 2011 supra note $37,23$.

44. ECOP 2012 supra note 16, at 18-25.

45. Id.

46. ECOP 2011, supra note 37 , at 8 .

47. James Brown, Pirates and Privateers: Managing the Indian Ocean's Private Security Boom, Lowy Institute FOR Int'L Pol'y, 3 (Sept. 2012), http://www.lowyinstitute.org/ files/brown_pirates_and_privateers_web.pdf.

48. Id.

49. Id. at 5 .

50. Id.

51. ECOP 2012 supra note 16, at 18.

52. ICC-IMB 2012 Report, supra note 17, at 5-6. See also Samihah Zaman \& Nada AlTaher, Successful piracy attempts decline in Gulf of Aden and Arabian Sea, Gulf News 
against piracy, it is not yet time for celebration, as piracy remains a significant global threat. ${ }^{53}$ One U.S. admiral who has commanded a task force off the coast of Somalia notes that Somali pirates have demonstrated their ability to adapt to the various defensive measures employed by ships: pirates have begun operating further out to sea to avoid naval patrols and have begun boarding ships at night to avoid ships' passive security measures. ${ }^{54}$ In fact, according to Donna Hopkins, Chair of the United Nations Contact Group on Piracy off the Coast of Somalia, pirates "still roam a huge part of the Indian Ocean as well as the Red Sea and the Gulf of Aden looking for vessels to hijack." 55

In short, while international efforts to combat Somali piracy have contributed to a decline in successful attacks, the efforts have not been able to stop piracy from appearing to be an attractive employment option. ${ }^{56}$ Somali pirates have found, and will continue to find, ways to overcome anti-piracy measures. ${ }^{57}$ Somali pirates will not likely be easily deterred from seeking out the huge profits that are the signature feature of the Somali piracy-for-ransom business model discussed below. ${ }^{58}$

\section{B. The Somali Piracy-For-Ransom Business Model}

Somali pirates stage their attacks using a somewhat predictable pattern. Teams of pirates approach a merchant vessel on any number of high speed skiffs, wielding automatic rifles and often rocket-propelled grenades. ${ }^{59}$ They typically launch from mother ships more than a thousand miles off the Somali coast. ${ }^{60}$ From their skiffs, the pirates board the merchant vessel, commandeer the ship under the threat of violence, and

(June 4, 2013), http://gulfnews.com/news/gulf/uae/crime/successful-piracy-attemptsdecline-in-gulf-of-aden-and-arabian-sea-1.1192614.

53. ICC-IMB 2012 REPORT, supra note 17, at 20 (warning against complacency); Chris Mgidu, EU naval force warns of piracy threats despite reduction off Horn of Africa, XINHUANET (Nov. 8, 2012), http://hiiraan.com/news4/2012/Nov/26761/eu_navalforce_ warns_of_piracy_threats_despite_reduction_off_horn_of_africa.aspx (quoting an EU representative as arguing against complacency); What happened to Somalia's pirates?, ECONOMist (May 19, 2013), http://www.economist.com/blogs/economist-explains/ 2013/05/economist-explains-11 "gains [against piracy] are fragile and reversible").

54. Admiral warns against withdrawing naval support on piracy, Maritime SECURITY INT'L (Oct. 24, 2012), http://www.maritimesecurityinternational.net/readnews.php?ide $=87$.

55. No Hijacking by Somali Pirates in Nearly a Year, MaritimeSecurity.Asia (May 5, 2013), http://maritimesecurity.asia/free-2/piracy-2/no-hijacking-by-somali-pirates-innearly-a-year- $2 /$.

56. See ICC-IMB 2012 RePort, supra note 17, at 5-6.

57. Admiral warns against withdrawing naval support on piracy, supra note 54.

58. See infra Part I.B.

59. See e.g., Rob Walker, Inside story of Somali pirate attack, BBC (June 4, 2009), http://news.bbc.co.uk/2/hi/africa/8080098.stm; see also ICC-IMB 2012 RePORT, supra note 17, at 22; Mgidu, supra note 53.

60. See, e.g., ICC-IMB 2012 REPORT, supra note 17, at 22; see also Richard Sisk, U.S. Navy captures 5 Somali pirates, siezes [sic] pirate mother ship off Kenya, Somali coasts, N.Y. DAILY News (Apr. 1, 2010), http://www.nydailynews.com/news/world/u-s-navy-cap tures-5-somali-pirates-siezes-pirate-mother-ship-kenya-somali-coasts-article-1.168171\#ix zz2XRQCGgAp. 
force the captain to steam towards the Somali coast. ${ }^{61}$

Staging an attack requires not only personnel, but also money. In Somalia, pirate attacks are typically financed in one of several ways. In some cases, a single entrepreneur provides the backing for a team or teams of pirates who seek out ships to hijack. ${ }^{62}$ Other pirate teams are organized so that individual pirates take an ownership stake in the venture and share in the proceeds. ${ }^{63}$ Finally and most commonly, organized criminal syndicates provide an opportunity for investors to fund multiple teams of pirates. ${ }^{64}$ Funding a team of pirates can require upwards of $\$ 250,000$ in startup costs. ${ }^{65}$ Both the investors and the on-the-water pirates get paid if and when the pirates are able to negotiate a ransom payment. ${ }^{66}$

Somali pirates use the piracy-for-ransom business model for several reasons. First, of course, the piracy-for-ransom business model is a lucrative one that enables pirates to reap multi-million dollar rewards. ${ }^{67}$ Second, Somali pirates do not have a real market in which to sell a hijacked ships' cargo. ${ }^{68}$ Third, Somali pirates have been successful at negotiating with local communities for safe harbors to anchor hijacked ships: pirates pay off government officials and members of local communities so that pirates can hold their hostages for long periods of time while they negotiate a ransom payment. ${ }^{69}$ Due to the protection afforded by safe harbors, the ransom negotiation phase can last for years, all to the detriment of hostage seafarers who either lose their lives or suffer severe physical and psychological trauma. ${ }^{70}$

The pirates usually employ a bilingual person to conduct negotiations, ${ }^{71}$ while ship owners usually entrust negotiations to professional negotiators. ${ }^{72}$ Unlike the Chandlers, most large scale commercial ship owners and operators whose ships steam through pirate-infested waters purchase kidnap and ransom insurance policies to aid them in the event of a hijacking. ${ }^{73}$ These policies provide for the assistance of professional cri-

61. Walker, supra note 59.

62. Financial Action Task Force, Organised Maritime Piracy and Related KidnapPING FOR RANSOM 17 (2011) [hereinafter FATF REPORT].

63. Id.

64. Id.

65. Chana Joffe-Walt, Behind the Business Plan of Pirates Inc., NPR (Apr. 30, 2009), http://www.npr.org/templates/story/story.php?storyId=103657301.

66. Id.

67. FATF REPORT, supra note 62 , at 8.

68. 2013 World Bank RePort, supra note 14, at xxiv, 109.

69. Id. at xxiv, 109-110.

70. See, e.g., Catherine E. Shoichet \& Neda Farshbaf, Ship crew held for 1,000 days rescued off coast of Yemen, CNN (Dec. 24, 2012), http://www.cnn.com/2012/12/24/ world/africa/somalia-pirate-rescue (describing that crewmembers of the Panamanian MV Iceberg 1 were held hostage by pirates for nearly three years); ECOP 2012, supra note 16 , at $11-12$.

71. 2013 World Bank Report, supra note 14, at 93.

72. Brown, supra note 47 , at 6 .

73. ECOP 2012, supra note 16, at 31. 
sis management, negotiation, and public relations teams. ${ }^{74}$ These policies also specifically cover ransom payments and can provide either worldwide or geographically-specific coverage for a term of years. ${ }^{75}$ This certainty of reimbursement and access to services comes at a cost of up to $\$ 12,500$ for a single transit through the high-risk area. ${ }^{76}$

When negotiations are complete, the ransom is delivered and distributed. ${ }^{77}$ According to the World Bank, the proceeds for an average ransom are split between the pirate crewmembers (who earn around $\$ 10,500$ each), guards and suppliers for the ship once it is anchored off the Somali coast (who earn $\$ 2-3$ per day), and those who contributed start-up capital and working capital to the operation (who earn back the $\$ 300,000$ to $\$ 400,000$ that was contributed to the operation). ${ }^{78}$ Investors also receive a percentage of the ransom proceeds. ${ }^{79}$ In addition, as much as $20 \%$ of the ransom proceeds are put aside to fund future attacks. ${ }^{80}$

One might think that even without a piracy ransom ban, pirates and those who invest in piracy could be stopped after-the-fact: by tracking the ransom payments and thereafter arresting and prosecuting recipients of the payments. Unfortunately, the evidence thus far seems to indicate otherwise. ${ }^{81}$ By way of example, consider the hijacking of the Danish-owned MV Danica White. After the ship was hijacked, the United States recorded the serial numbers of the bills composing the US $\$ 1.2$ million that was paid as ransom to the pirates, and also shared the information with Danish authorities. ${ }^{82}$ Nevertheless, neither the U.S. nor Danish authorities was ever able to trace any of the bills, likely because of the ease with which money is laundered in Somalia. ${ }^{83}$

\section{The Ethical Dilemma of Banning Ransom Payments}

The above discussion shows that states and ship owners have employed a variety of tactics in an effort to stop pirates from attacking and

74. Jay MacDonald, Firms snatch up kidnap and ransom insurance, BANKRATE (Oct. 30, 2012), http://www.bankrate.com/finance/insurance/kidnap-ransom-insurance.aspx. These policies may also cover: reimbursement of any ransom payments lost in transit; legal defense if a kidnapped employee sues; any travel expenses related to ransom payment; medical and psychiatric rehabilitation of victims; payment of salaries to kidnapped persons' families for the duration of the kidnapping; and repatriation, burial, and cremation services for victims. See id. See also Kidnap and Ransom, Aon Risk Solutions, http://www.aon.com/attachments/risk-services/2012-Kidnap-and-Ransom .pdf (last visited Jan. 21, 2014) [hereinafter Aon Risk Solutions].

75. See, e.g., Aon Risk Solutions supra note 74.

76. ECOP 2012 supra note 16 , at 33.

77. Walker, supra note 59.

78. 2013 WORLD BANK RePORT, supra note 1415, at 110-15.

79. Id. at 114 .

80. See, e.g., Nikolas K. Gvosdev, Privateering the Pirates, Nat'L Int. (Apr. 10, 2009), http://nationalinterest.org/article/privateering-the-pirates-3082.

81. ECOP 2012, supra note 16, at 28. (detailing that though there were 1,190 pirates captured worldwide in 2012, there were only 21 completed piracy trials).

82. FATF REPORT, supra note 62, at 11.

83. Id. at 11,15 . 
hijacking ships. Yet even if those anti-piracy tactics are effective in reducing piracy in the short-term, some commentators argue that the best way to deter would-be pirates from choosing piracy as a career option-thereby better protecting seafarers from a continued threat of hijackings and hostage-takings - is to eliminate ransom payments. ${ }^{84}$ In other words, if one eliminates ransom payments, one takes away the pirates' opportunities to profit from their illegal activities, and also takes away the funds necessary for pirates to stage additional successful attacks. The U.N. Monitoring Group on Somalia tasked with investigating arms embargo violations in Somalia supports this approach. ${ }^{85}$ The Monitoring Group reported:

$[T]$ here is no escaping the importance of escalating ransom payments in fuelling the growth of piracy (and the related crime of kidnapping) and in financing violations of the arms embargo. Piracy attacks have become the most lucrative economic activity in Somalia, and the pirates are using part of the ransom monies to upgrade their arsenals in order to become more effective and efficient in their operations. Unless international action is able to reverse the cost-benefit ratio that drives the piracy phenomenon, it is likely to remain a scourge to international shipping in the Gulf of Aden and Indian Ocean and to peace and security in Somalia. ${ }^{86}$

But is a piracy ransom ban a legal and practical solution to the problem of maritime piracy? To set the stage for our analysis of this precise question in the sections that follow, we first address the underlying ethical dilemma that necessarily informs any decision about whether to ban ransom payments: whether to sacrifice innocent lives in the short term to realize the potential long-term goal of deterring future criminal activity. We begin with a discussion of countries' general ransom policies to show how some states have thus far grappled with and resolved this ethical dilemma.

84. See, e.g., Paul Lansing \& Michael Petersen, Ship-Owners and the Twenty-First Century Somali Pirate: The Business Ethics of Ransom Payment, 102 J. Bus. Ethics 507, 513 (2011) (proposing that the shipping industry mandate a no-ransom policy for all firms as part of a several-pronged plan for solving the piracy problem); Abdon M. Pallasch, Kirk: U.S. should say no to pirate ransoms, CHI. Sun Times (May 6, 2011), http://www .suntimes.com/news/5220031-418/kirk-u.s.-should-say-no-to-pirate-ransoms (proposing that the U.S. should push for a total ban on piracy ransoms, even though it may pose a threat to hostages, because it is the "best long-term strategy to cripple the industry"). See also Meadow Clendenin, Comment, "No Concessions" with No Teeth: How Kidnap and Ransom Insurers and Insureds are Undermining U.S. Counterterrorism Policy, 56 EMORY L.J. 741, 772-73 (2006) (arguing that the insurance industry generally should adopt a policy of not insuring against, or reimbursing for, ransom payments to kidnappers and terrorists); Hopkins, supra note 29 (reporting on Prime Minister David Cameron's speech at the London Conference on Somalia calling for a task force on ransoms with the ultimate objective of ending ransom payments to pirates). But see Richard Neylon, Banning Ransom Payments to Somali Pirates would Outlaw the Only Method a Shipowner has to Remove his Crew from Harm's Way and Rescue his Vessel and Cargo, Lloyd's List (Nov. 1, 2011), http://www.hfw.com/downloads/HFW-LL\%20Article\%20-\%20Ban\%20 Ransom\%20Payments\%20\%5bA4\%204pp\%5d\%20February\%202012.pdf (rejecting calls to ban ship owners and private individuals from paying piracy ransoms).

85. Rep. of the Monitoring Grp. on Som. pursuant to S.C. resolution 1811 (2008), II 266, U.N. Doc. S/2008/769 (Dec. 10, 2008), available at http://www.un.org/ga/search/ view_doc.asp?symbol=S/2008/769.

86. Id. 
We then address this ethical dilemma in the specific context of maritime piracy by setting out the arguments that have been advanced by various stakeholders in support of and against banning piracy ransom payments.

\section{A. Countries' Ransom Policies}

Some governments have "no concessions" policies: these countries will not negotiate with hijackers. ${ }^{87}$ They have essentially resolved the ethical dilemma of banning ransom payments in favor of the long-term goal of reducing the risk of future illegal activity. ${ }^{88}$ For example, the United States reports that it will make "no concessions" to anyone who takes its citizens hostage. ${ }^{89}$ The government states that while it "will use every appropriate resource to gain the safe return of American citizens who are held hostage ... the [official] policy [is] to deny hostage-takers the benefits of ransom, prisoner releases, policy changes, or other acts of concession." 90 The comments of the United States' Under Secretary for Terrorism and Financial Intelligence, David S. Cohen, explain the government's rationale underlying the "no concessions" policy. ${ }^{91}$ He stated:

I think there is no doubt that the payment of ransom just fuels the appetite for additional kidnapping operations, and that is true whether it's Somali pirates, a terrorist organization, a drug gang-it's true across the board. So point number one is we firmly believe that the right approach is to get to a place where ransoms are not paid and that the people who are contemplating that tactic recognize that there is no pot of gold at the end of the rainbow. ${ }^{92}$

Other countries make similar points in support of their "no concessions" policies. Britain's Foreign Secretary made the following comments after Somali pirates released the Chandlers: "Hostage taking is fundamentally wrong, and the Government will never reward hostage taking. People will understand the position of successive British governments that we do

87. FATF REPORT, supra note 62, at 23.

88. In fact, some scholars have found empirical evidence to support the wisdom of the "no concessions" policy: namely, that "[p]ast concessions have the strongest impact on generating future kidnapping events." Patrick T. Brandt \& Todd Sandler, Hostage Taking: Understanding Terrorism Event Dynamics, 31 J. Pol. Modeling 758, 758 (2009).

89. Press Statement by Richard Boucher, International Terrorism: American Hostages, U.S. Dep't Sт. (Feb. 20, 2002), http://2001-2009.state.gov/r/pa/prs/ps/2002/8190 .htm.

90. Id. At a Security Council Debate on Piracy and Somalia in November 2009, U.S. Ambassador Rosemary DiCarlo urged other states to adopt this same "no concessions" policy when dealing with pirates so as to cease encouraging pirates to further engage in illegal activities. Rosemary A. DiCarlo, U.S. Ambassador \& Alt. Representative for Special Political Affairs, U.S. Mission to the U.N., Remarks at a Security Council Debate on Piracy and Somalia, in the Security Council Chamber (Nov. 18, 2009) available at http:/ /usun.state.gov/briefing/statements/2009/132070.htm.

91. Interview by Xenia Dormandy with David S. Cohen, U.S. Under Sec'y for Terrorism \& Fin. Intelligence, Transcript Q\&A: Kidnapping for Ransom: The Growing Terrorism Financing Challenge, СнатнAм House, 9 (Oct. 5, 2012), http://www.chathamhouse.org/ sites/default/files/public/Meetings/Meeting\%20Transcripts/051012CohenQA.pdf [hereinafter Cohen Q \& A].

92. Id. 
not pay ransoms or make significant concessions otherwise there would be a risk of many more hostage takings." 93 Australia's government makes a comparable point in support of its "no ransom" policy, explaining that paying ransoms would only encourage the kidnapping-for-ransom business in general and put more lives at risk. ${ }^{94}$ Even when confronted with threats by hostage-takers to harm innocent victims, both Australia and the Philippines noted that they have strict policies of refusing to pay ransoms-precisely because they believe that paying would encourage additional kidnappings. ${ }^{95}$

Not all governments, however, are apparently as willing to stand by an unequivocal policy against paying ransoms. ${ }^{96}$ Reports indicate that some Western European countries have been persuaded to accede to ransom demands in an effort to save innocent lives in the short-term, notwithstanding a stated policy to the contrary. ${ }^{97}$ Commentators have charged that in

93. Announcement that Foreign Secretary welcomes release of the Chandlers, GOV.UK (Nov. 15, 2010), https://www.gov.uk/government/news/foreign-secretary-welcomesthe-release-of-the-chandlers. See also UK defends not paying pirates ransom for kidnapped pair, BBC (Feb. 1, 2010), http://news.bbc.co.uk/2/hi/uk_news/england/kent/8491301 .stm (quoting a Foreign Office spokesperson who defended the British government's policy to not make or facilitate concessions to hostage-takers). The U.K. Foreign Secretary explained this point even further in his remarks to the U.N. Security Council during a briefing on terrorism. William Hague, Member of Parliament, Foreign Secretary Supports UN Efforts Against Terrorism, Condemns Ransom Payments to Terrorists (Sept. 27, 2010), available at https://www.gov.uk/government/speeches/foreign-secretary-sup ports-un-efforts-against-terrorism-condemns-ransom-payments-to-terrorists. The Foreign Secretary urged against understanding ransom payments to hostage-takers "as a 'necessary evil' or as a legitimate tool for resolving kidnaps." Id. Instead, he argued that paying millions to hostage-takers will only "encourage more kidnaps and fund murder," given that successful hijackings can be mounted at a cost which is only a small fraction of the potential ransom reward. Id.

94. Daniel Flitton, No-ransom policy to stay, Sydney Morning Herald (Sept. 27, 2012), http://www.smh.com.au/federal-politics/political-news/noransom-policy-to-stay20120926-26lii.html (quoting an Australian Foreign Affairs Department official as saying that "[c]hanging the relevant legislation would undermine Australia's no-ransom policy, and indirectly result in Australians overseas being targeted").

95. Al Jacinto \& Lindsay Murdoch, Australian hostage's ransom investigated, SYDNEY Morning Herald (Apr. 11, 2013), http://www.smh.com.au/national/australian-hos tages-ransom-investigated-20130410-2hln5.html (reporting that both the Australian and Philippines governments have strict policies against paying ransoms to hostage-takers so as not to encourage further kidnappings). See also Arlene Paredes, Philippines Says No Ransom for Kidnapped Australian Warren Rodwell, InT'L Bus. Times (Jan. 6, 2012), http:// au.ibtimes.com/articles/277295/20120106/philippines-ransom-kidnapped-australianwarren-rodwell-video.htm.

96. Aid worker kidnappings rise, fuelling debate over ransom, IRIN (Mar. 21, 2013), http://www.irinnews.org/report/97697/aid-worker-kidnappings-rise-fuelling-debateover-ransom ("[C]ountries such as France, Germany and Spain are alleged to have paid tens of millions of dollars over the past decade to secure the release of nationals taken hostage by groups linked to Al Qaeda in the Islamic Maghreb (AQIM), circumventing the prohibitions [on paying ransoms] by making the payments through intermediaries. This put [sic] such countries at odds with the UK and the US, which refuse to pay ransoms, even indirectly.").

97. Id. See also The ransom business: Blood Money, EConomist (Nov. 6, 2013), http:// www.economist.com/blogs/baobab/2013/11/ransom-business (detailing ransoms allegedly paid by the French government, and detailing the French government's corresponding unwillingness to admit that such ransoms were paid). 
the past decade, Western European governments have paid between $\$ 70$ and $\$ 130$ million in cash to al-Qaeda and other militant groups, through intermediaries, in order to persuade those groups to release hostages from captivity. ${ }^{98}$ Persons critical of the payments argue that the monies keep terrorist organizations well-stocked, and also provide terrorist organizations with monies to recruit. ${ }^{99}$ Critics also argue that without strict adherence to a "no concessions" policy, terrorists will continue to rely on taking ransoms in exchange for releasing European hostages to fund their operations. ${ }^{100}$ Whether such arguments will persuade governments remains to be seen. However, French President François Hollande has recently made clear that France will be enforcing a strict policy against negotiating with hostage-takers, insisting that France will instead rely on military force to rescue French citizens taken hostage. ${ }^{101}$

Yet even if governments are willing to sacrifice lives in the short term in favor of a long-term goal of deterring future criminal activity, only a few countries currently have, or have had, laws prohibiting their private citizens or corporations from paying ransoms. ${ }^{102}$ For example, Italy has a law allowing the government to freeze the assets of the families of kidnapping victims so that the families are discouraged from acceding to ransom demands. ${ }^{103}$ In the early 1990s, Colombia sought to combat its overwhelming kidnapping epidemic via an anti-abduction law criminalizing the payment of ransoms, though its Constitutional Court later struck down portions of the law as unconstitutional. ${ }^{104}$ In Somalia, even though ran-

98. See, e.g., Alexandria Sage \& Sophie Louet, France plays down report of ransom paid for Niger hostages, Reuters (Feb. 8, 2013), http://www.reuters.com/article/2013/ 02/08/us-france-hostages-idUSBRE9170UQ20130208 (quoting the former U.S. Ambassador to Mali as saying that though European governments deny it, they have "paid about $\$ 89$ million between 2004-2011 to secure hostages' freedom"); Lara Vergnaud, France won't negotiate with kidnappers, despite political risks, Blouln News (Feb. 28, 2013), http://blogs.blouinnews.com/blouinbeatworld/2013/02/28/france-wont-negoti ate-with-kidnappers-despite-political-risks/ ("In the past decade alone, Britain, Germany, Italy, Spain, France, Austria, Sweden and the Netherlands have paid over \$130 million in ransom, mainly through intermediaries, to terrorists holding European hostages."); Vivienne Walt, Terrorist Hostage Situations: Rescue or Ransom?, Time (Oct. 12, 2010), http://www.time.com/time/world/article/0,8599,2024420,00.html (reporting that Algerian officials claim that between 2003 and 2010, Western European governments have paid the bulk of the more than $\$ 70$ million that has been paid to al-Qaeda-linked groups for the release of hostages).

99. See, e.g., Walt, supra note 98; see also Former US Ambassador Says France Indirectly Paid Islamist Militants, VOA (Feb. 8, 2013), http://www.voanews.com/content/for mer-us-ambassador-says-france-indirectly-paid-islamist-militants/1599726.html.

100. Vergnaud, supra note 98.

101. Anne Giudicelli, France: A New Hard Line on Kidnappings?, Combating Terrorism Center (Apr. 29, 2013), http://www.ctc.usma.edu/posts/france-a-new-hard-line-on-kid nappings.

102. Lansing \& Petersen, supra note 84 , at 507.

103. Celestine Bohlen, Italian Ban on Paying Kidnappers Stirs Anger, N.Y. Times (Feb. 1, 1998), http://www.nytimes.com/1998/02/01/world/italian-ban-on-paying-kidnappers-stirs-anger.html.

104. Laurie Goering, In Colombia, Kidnapping is Big Business, CHI. TRIB. (Dec. 8, 1996), http://articles.chicagotribune.com/1996-12-08/news/9612080298_1_anti-kid napping-kidnapping-is-big-business-editor-of-el-tiempo Hargrove v. Underwriters at 
som payments are prevalent, the government has stated that its laws make paying ransoms illegal. ${ }^{105}$ In 2011, Somalia charged three Britons and one American with violating the no-ransom law after the Britons and the American had brought millions of dollars in ransom payments into Somalia. ${ }^{106}$ Somalia later pardoned the men, who had been facing jail sentences, but the millions of dollars were confiscated and permanently retained by the Somali government. ${ }^{107}$

Although many governments may seek to discourage their private citizens and organizations from paying ransoms, they do not at present criminalize the conduct. ${ }^{108}$ For example, neither the United States nor the United Kingdom bans its private citizens from paying ransoms, though both counsel against the practice so as not to encourage future kidnappings. ${ }^{109}$ In other words, states have thus far tended not to force private citizens whose loved ones are held hostage to pay the price for any longterm progress that might be gained against the hostage-takers.

\section{B. Banning Piracy Ransoms: Arguments For and Against}

As noted above, these same concerns that ransom payments fuel further criminal activities and put lives at stake have caused some commentators to call for banning both states and citizens from paying piracy ransoms. ${ }^{110}$ These very concerns prompted Prime Minster David Cameron in early 2012 to call for the creation of a task force to study options for ending ransom payments to pirates. ${ }^{111}$ Secretary of State Hillary Clinton supported Cameron's "initiative to create an international task force to discourage the payment of ransoms to pirates and other groups to eliminate the profit motive and prevent the illicit flow of money and its corrosive

Lloyd's, London, 937 F. Supp. 595, 600 (S.D. Tex. 1996) (discussing a Colombian law prohibiting individuals from paying ransoms to kidnappers, and discussing the Colombian Constitutional Court's decision to strike down portions of the law as unconstitutional).

105. Mohamed Ahmed, Somalia jails Britons, American over pirate ransom, ReUTERS (June 19, 2011), http://in.reuters.com/article/2011/06/19/idINIndia-577809201106 19.

106. Id.

107. Somalia: Three Britons pardoned by president, BBC (June 26, 2011), http://www .bbc.co.uk/news/world-africa-13918991.

108. Lansing \& Petersen, supra note 84, at 507 ("While most federal governments have non-ransom policies when dealing with piracy, few international, U.S., or other national laws prohibit private citizens or corporations from paying ransom demands.").

109. Press Statement by Richard Boucher, supra note 89 (discussing the U.S. policy of discouraging U.S. citizens from acceding to ransom demands); see Kidnap ransom refusal under fire, EXPRESS (Feb. 1, 2010), http://www.express.co.uk/news/uk/155582/Kidnapransom-refusal-under-fire (reporting that a nonprofit organization in position to make a ransom payment to the pirates holding the Chandlers was unable to proceed with the payment after the U.K. government refused to give its cooperation).

110. See supra notes 84-86 and accompanying text.

111. Colin Freeman, Why David Cameron will not stop Somali pirates getting their pieces of eight, Telegraph (Sept. 6, 2012), http://blogs.telegraph.co.uk/news/colinfree man/100179584/why-david-cameron-will-not-stop-somali-pirates-getting-their-pieces-ofeight/. Prime Minister Cameron initiated the task force because he believed that the ransom payments "only ensure that crime pays." Id. 
effects." 112 Twelve additional states joined in the call, and in 2012, they created an International Piracy Ransoms Task Force to forward policy proposals recommending "how to avoid, reduce or prevent the payment of ransoms," with the ultimate objective of insuring that pirates do not profit from ransom payments and as a result "abandon the practice of kidnapping for ransom." 113

The support for a task force to study the potential prevention of piracy ransoms was not universal, however. ${ }^{114}$ Indeed, maritime organizations representing ship owners advanced a number of arguments opposing a potential ban-arguments that resolve the ethical dilemma in favor of saving innocent lives in the short term. ${ }^{115}$ For example, INTERTANKO, an organization representing independent tank owners and operators of oil and chemical tankers, ${ }^{116}$ stated: "We must be certain that we can do whatever is necessary to secure [crews'] release in the event they are taken hostage. Payment of ransoms is the only guaranteed way to secure our seafarers' lives." 117 INTERTANKO has also taken issue with the claim that banning ransoms "will persuade pirates to stop attacking vessels," instead arguing that pirates will only become more violent in order to obtain the "prize a ransom payment promises." 118 INTERTANKO has also emphasized the potential environmental damage that could occur should pirates capture a ship carrying a good like crude oil, only to thereafter abandon the ship when no ransom payment is forthcoming. ${ }^{119}$

Maritime industry representatives do not necessarily disagree that ransom payments fuel the continued existence of maritime piracy. They nevertheless argue that despite naval patrols, armed guards, and the use of

112. Hillary Rodham Clinton, Secretary of State, Secretary Clinton's Remarks at London Conference on Somalia (Feb. 23, 2012), available at http://iipdigital.usembassy .gov/st/english/texttrans/2012/02/20120223143901su0.5437062.html\#axzz2UfWCtv dg.

113. International Piracy Ransoms Task Force, Final Report, at 3 (2012) (on file with author).

114. See e.g., Letter from Yudhishthir Khatau, Chairman, BIMCO et al., to David Cameron, Prime Minister, U.K. (Mar. 14, 2012), available at http://www.intertanko.com/ Global/Prime\%20Minister\%20David\%20Cameron\%20140312.pdf.

115. Id.; see also Michele White, Gen. Counsel, INTERTANKO, Shipping Industry Submission to International Task Force on Ransom Payments (May 30, 2012), available at http://www.intertanko.com/News-Desk/Home-Page-Article/UK-led-piracy-Ransom-

Task-Force-debates-ransom-ban-/ (follow "found here" hyperlink to view "full text of Michele's intervention"); see also Letter from Alastair Evitt, Chairman, SOS SaveOurSeafarers, to David Cameron, Prime Minister, U.K. (Mar. 14, 2012), available at http:// www.intertanko.com/News-Desk/Home-Page-Article/UK-led-piracy-Ransom-Task-Forcedebates-ransom-ban-/ (follow "SOS letters" hyperlink).

116. About Us, INTERTANKo (Dec. 9, 2013), http://www.intertanko.com/About-Us/.

117. White, supra note 115; Letter from Alastair Evitt, supra note 115; ("The consequences of not paying are too terrible to contemplate as Somali pirates vent their frustration on innocent seafarers."); Letter from Yudhishthir Khatau, supra note 114. ("To hinder or prevent ... ransom payments would seriously and unnecessarily expose seafarers and deprive ship-owners of their last means of protecting the safety of their employees at sea).

118. White, supra note 115.

119. Id. 
more passive defensive measures, pirates still manage to hijack ships. ${ }^{120}$ Moreover, they argue that absent military intervention-which they charge is frequently not employed-ship owners have no choice but to pay in order to prevent their crewmembers from being killed. ${ }^{121}$ In support of this claim, INTERTANKO has referenced the hijacking of the Iceberg 1.122 During the 800 days that no ransom was paid and the crew was held hostage, one crewmember committed suicide and another six (citizens of Yemen, India, the Philippines, Ghana, Sudan, and Pakistan) were close to death. ${ }^{123}$

On this same point regarding a lack of other viable options to secure the safety of crewmembers, the English High Court apparently agrees. ${ }^{124}$ In Masefield v. Amlin Corp. Member Ltd., ${ }^{125}$ the court concluded that piracy ransom payments did not violate currently binding English law or public policy. ${ }^{126}$ Furthermore, the court explained that in its view, diplomacy would not likely provide a means of releasing captured ships, given the absence of any national administration in Somalia. ${ }^{127}$ In addition, it noted that "[m]ilitary intervention involves legal and technical difficulties, and raises a risk to captured crews." 128 Instead, the court suggested that "the only realistic and effective manner of obtaining the release of a vessel is the negotiation and payment of a ransom."129

In December 2012, the Task Force issued its Final Report, making four recommendations - all addressing ways to better protect against hijackings and to better respond to them should they occur. ${ }^{130}$ For reasons unknown, the Task Force did not tackle in its Final Report the legality or practicality of a potential piracy ransom ban. ${ }^{131}$

This Article addresses these questions left open by the Task Force Final Report. It does so even though we do not disagree with the Task

120. Letter from Yudhishthir Khatau, supra note 114 ("It is well understood that the payment of ransoms only fuels the problem, however as long as ships are hijacked and seafarers are held for ransom, there is no alternative.").

121. White, supra note 115 (stating that ship owners pay ransom because there appears to be little appetite for military intervention, and that failing payment, crewmembers will suffer harm).

122. Id.

123. Id.

124. See Masefield v. Amlin Corp. Member Ltd., [2011] EWCA (Civ) 24, [2009] Q.B. 260 (Eng.).

125. Id.

126. Id. at $[63,74]$.

127. Id. at $[6,78]$.

128. Id. at [6].

129. Id. at [6].

130. See International Piracy Ransoms Task Force, supra note 113, at 2 (recommending (1) a strategic partnership between various stakeholders to break the piracy business model; (2) developing a more coordinated approach to sharing information and evidence to ensure that pirates are prosecuted; (3) strengthening coordination between stakeholders to ensure that they are prepared for hostage situations; and (4) encouraging greater compliance with anti-piracy defensive measures). See also Announcement that Piracy Ransoms Task Force publishes recommendations, Gov.uk (Dec. 11, 2012), https://www.gov.uk/government/news/piracy-ransoms-task-force-publishesrecommendations.

131. See International Piracy Ransoms Task Force, supra note 113. 
Force's conclusion that the world community should work together to better protect ships against being hijacked, and to better ensure an effective and appropriate response should a hijacking occur. ${ }^{132}$ Nevertheless, some commentators have suggested that an outright ban on ransom payments could put an end to piracy as a global threat. ${ }^{133}$ We expect those calls will likely continue, especially if pirates continue with any regularity to hijack ships and hold their crews hostage in exchange for ransom payments. We hope our analysis will advance the conversation about whether a piracy ransom ban does, in fact, offer a promising tool for solving the problem of maritime piracy.

\section{Analyzing the Legality of a Piracy Ransom Ban}

In this section of the Article, we analyze whether criminalizing ransom payments would be consistent with the retributive principles of the criminal law. Retribution is a moral justification for the imposition of criminal punishment. According to retributive principles, the state is justified in imposing criminal sanctions on those who deserve it: those who are guilty. ${ }^{134}$ We ask whether punishing ship owners and other individuals who pay a ransom, in exchange for the safe release of innocent victims, is consistent with the criminal law's retributive aims. Should the criminal law punish those who pay piracy ransoms under these circumstances, or should these individuals be spared the imposition of sanctions?

We explore these questions by comparing the potential crime of paying piracy ransoms to other similar conduct where one makes a payment to a person or organization engaged in criminal activities. Based on this definition of "other similar conduct," we examine how the criminal law in the United States ${ }^{135}$ treats those who engage in the following types of conduct: (1) paying ransoms to kidnappers; (2) making payments in response to extortionate threats; and (3) paying bribes. Because it also involves punishing individuals for making payments, possibly even when under duress, we also consider the United States' law that criminalizes financing terrorism.

132. Id. at 2 .

133. Lansing \& Petersen, supra note 84 , at 513 ("The shipping industry must collectively mandate a no-ransom policy for all firms.").

134. See Michael Moore, Placing Blame: A General Theory of the Criminal Law 91 (1997) ("Retributivism is a very straightforward theory of punishment: We are justified in punishing because and only because offenders deserve it."); John Bronsteen, Retribution's Role, 84 IND. L.J. 1129, 1129 (2009) (noting that retributivists justify punishment based on the wrongdoing of the offender).

135. One reason we refer to United States law to examine this question of criminalizing ransom payments is because it is the law with which we are most familiar. We nevertheless expect the analysis would be similar if one referenced the laws of other countries following the common law or civil law traditions, because they, too, will typically require "criminal intent" in order to punish individuals for violating the criminal law. See, e.g., Greg Taylor, Concepts of Intention in German Criminal Law, 24 OxFord J.L. STUD. 99, 99 (2004) (describing how intent is required in order for someone to be convicted of attempted murder in Germany). 


\section{A. Kidnapping, Extortion, and Bribery}

Where kidnap for ransom, extortion, and bribery are concerned, it is evident that each involves a payment to another-just as does paying a ransom to pirates in exchange for a release of hostages. For simplicity and consistency purposes, we use the federal criminal law of the United States to illustrate. ${ }^{136}$ For example, 18 U.S.C. \& 1201 makes it a federal crime to kidnap and hold any person for ransom or reward, or to attempt or conspire to kidnap another for ransom or reward. ${ }^{137}$ Extortion is also a federal crime. ${ }^{138}$ Specifically, the Hobbs Act, 18 U.S.C. \& 1951, makes it a crime to obstruct, delay, or affect commerce by extortion, or to attempt or conspire to do the same. ${ }^{139}$ The statute defines "extortion" as "the obtaining of property from another, with his consent, induced by wrongful use of actual or threatened force, violence, or fear, or under color of official right."140 18 U.S.C. \& 201 criminalizes "corruptly" giving or offering something of value to a public official "with intent" to "influence any official act," or "with intent" to influence an official to commit or allow a fraud against the United States. ${ }^{141}$ The same statute subjects any public official to punishment who "corruptly" demands, seeks, or receives anything of value in return for being influenced to commit any official act, who does or fails to do any act in violation of official duties, or who commits any fraud against the United States. ${ }^{142}$ Although we focus on federal criminal law, states also criminalize the same or similar conduct. ${ }^{143}$

Of the three different crimes, however, only bribery subjects the person who makes a payment to punishment. ${ }^{144}$ In the kidnapping and extortion context, the person or entity receiving a payment-not the person

136. Limiting our review to federal criminal law, rather than the laws of 50 different states, makes sense in this context, where the purpose is to help facilitate a general analysis of whether piracy ransom payments should be criminalized. The focus on federal criminal law also makes sense because maritime piracy is a federal offense under 18 U.S.C. \& 1651 (2012). Because piracy is a federal offense, any criminalization of piracy ransom payments also would likely occur at the federal level.

137. The federal kidnapping statute requires a federal nexus to apply. 18 U.S.C. $\S 1201$ (2012). For example, the kidnapper must travel over state lines, use the mails or any instrumentality of interstate or foreign commerce to further commission of the offense, or kidnap a foreign official. Id.

138. 18 U.S.C. \& 1951 (2012).

139. Id.

140. Id. For this analysis, we do not focus on the part of the Hobbs Act that deals with extortion "under color of official right."

141. 18 U.S.C. § 201 (2012).

142. Id.

143. See, e.g., Cal. Penal Code $\S \S 207,209$ (West 2013) (defining the crime of kidnapping to include forcibly taking, holding, or detaining another person, and also criminalizing kidnapping for ransom or reward); Cal. Penal Code $\S 520$ (West 2013) (making it a crime to "extort[ ] any money or other property from another . . . by means of force, or any threat"); Cal. Penal Code $\S \S 7$ (West 2013) (defining "bribe" as "anything of value ... or any promise or undertaking to give any, asked, given, or accepted, with a corrupt intent to influence, unlawfully, the person to whom it is given, in his or her action, vote, or opinion"); CAL. Penal Code §§ 67-68 (West 2013) (criminalizing the conduct of persons who offer or accept bribes).

144. Compare 18 U.S.C. \& 1201, and 18 U.S.C. § 1951, with 18 U.S.C. § 201. 
making the payment-is the one whose behavior is considered criminal. ${ }^{145}$ Why is there such a distinction in treatment? Here, we focus on the mental state component of criminal liability. The relevant criminal law statutes' retributive principles subject to criminal sanctions those who demand a ransom, or who make a threat to obtain money or other property, because those individuals have intentionally engaged in wrongful acts. Those who only pay, however, are treated as victims because they do not intend to engage in wrongful acts, even though by the fact of their payments they are in some sense furthering criminal activity. The criminal law does not subject the payer to punishment because the payer does not have a sufficiently culpable mental state: because he acted under duress, he does not deserve to be punished. In fact, by its very definition, extortion occurs when one is required to pay money under duress or coercion. ${ }^{146}$

As Professor Joshua Dressler explains, duress implicates threats rather than offers. ${ }^{147}$ An individual acts under duress if he does something in response to a threat by another to make himself worse off than he would have been otherwise. ${ }^{148}$ In other words, he acts only because of fear or coercion. ${ }^{149}$ By contrast, one does not act under duress if he responds to an offer to improve his position. ${ }^{150}$ In such cases, we conclude that the individual's acts are more voluntary since they are prompted by desire, as opposed to fear. ${ }^{151}$ "Intuitively, society believes that conduct is freer when individuals respond to temptations than when they act out of fear." 152 When individuals act out of fear in response to a threat to make them worse off than they otherwise would have been, they can claim the legal defense of duress, and their acts will be imputed to the one who made the threat. 153

The legal defense of duress does not apply to any and all threats, however. ${ }^{154}$ For the defense to be available, the threat must come from a person and be an unlawful threat to imminently cause death or great bodily harm to a human being. ${ }^{155}$ The one receiving the threat must not also have been at fault for putting himself in the situation to be coerced. ${ }^{156}$ For example, one who joins a criminal organization, and thereafter commits an

145. See 18 U.S.C. $\S \S 1201,1951$.

146. See 18 U.S.C. \& 1951; United States v. Addonizio, 451 F.2d 49, 77 (3d Cir. 1971) ("[T] he essence of extortion is duress"). See also Steven J. Mulroy, "Official" Explanation: Defining "Official Capacity" and Related "Color of Office" Phrases in Bribery and Extortion Law, 38 U. Mem. L. Rev. 587, 598-99 (2008) (noting that extortion payments are often coerced).

147. Joshua Dressler, Exegesis of the Law of Duress: Justifying the Excuse and Searching for its Proper Limits, 62 S. CAL. L. Rev. 1331, 1336 (1989).

148. See id.

149. See id. at 1336-37

150. Id. at 1337 .

151. Id.

152. Id.

153. See id. at $1337,1339$.

154. See id. at 1339.

155. Id.

156. Id. at 1341. 
unlawful act in response to a threat from a member of the criminal organization, will not be able to claim the defense of duress. ${ }^{157}$

The criminal law treats as victims those who pay kidnappers and those who give in to extortionate demands. ${ }^{158}$ In both cases, the individual pays money because of a threat to cause wrongful harm to others or to themselves. In neither case is the individual responding to an offer or enticement or in any sense acting to improve his position from what it otherwise would have been. In the case of kidnapping, the payer accedes to the ransom demand so as to save the life of an innocent victim. The payer accedes to extortionate demands for the same reason: in response to a threat to make the payer or others worse off than they otherwise would have been. In short, in both cases, the payers are victims. In both cases, payers act similarly to those who "give up" a purse or a wallet to a robber in order to avoid being harmed - the criminal law treats these persons as victims, not perpetrators, despite the fact that handing one's purse over to a robber in some way facilitates the robbery. ${ }^{159}$

One who pays a bribe, by contrast, can be criminally liable for making a payment, but only because he acts with the required "corrupt intent"-the intent to receive a quid pro quo or specific benefit in return for the payment to one in a position of trust. ${ }^{160}$ With a bribe, one pays knowingly and willingly to receive the illicit benefit of better than fair treatment. ${ }^{161}$ In other words, he pays voluntarily in an effort to improve his own situation from what it otherwise would be absent the payment. ${ }^{162}$ Of course, even one who pays in the bribery context could claim that his payment was not truly willingly made: he paid only because he knew there was no other way to get the official, for example, to provide a contract or a license to do business. In this case, the law would not excuse the payer's conduct because the payer is still just seeking a benefit to improve his situation. ${ }^{163}$ On the other hand, what may appear to be bribery becomes acceding to an extortionate demand under circumstances where the payment is in

\section{Id.}

158. Id. at 1341. The duress defense is applicable to our analysis, while the defense of necessity is not. Necessity is a defense that is typically available only in response to natural forces: for example, it is available when one commits a crime that would constitute the lesser of two evils in response to a naturally-caused condition, such as a hurricane. Id. at 1347. Our concern in this article is threats from people, not threats from naturally-caused conditions.

159. See, e.g., Unintended Consequences: Refugee Victims of the War on Terror, Georgetown Univ. Law Ctr., Human Rights Inst.,23 n.157 (Mark Fleming et al. eds., 2006) [hereinafter Georgetown Unintended Consequences] ("In the criminal context, an individual forced to give money or goods to an armed group would be considered a victim of criminal extortion, not a participant in the crime under U.S. criminal law.").

160. See 18 U.S.C. \& 201(b) (requiring a showing of "corrupt intent"); United States v. Muldoon, 931 F.2d 282, 287 (4th Cir. 1991) (defining corrupt intent as used in 18 U.S.C. \& 201(b)).

161. See James Lindgren, The Theory, History, and Practice of the Bribery-Extortion Distinction, 141 U. PA. L. Rev. 1695, 1698-99 (1993).

162. See, e.g., United States v. Addonizio, 451 F.2d 49, 77 (3d Cir. 1971).

163. See, e.g., Lindgren, supra note 161, at 1699. 
response to a threat of violence. ${ }^{164}$ For example, if the individual makes a payment because he understands that his building will be destroyed should he fail to pay an official, he will be acting only out of fear, and will not be acting so as to gain better than fair treatment. ${ }^{165}$ In such a case, the culpable mental state of "corrupt intent" in making the payment is absent. ${ }^{166}$

Based on this analysis of current and comparable United States law, one who pays a piracy ransom should not be criminally liable because he acts under duress. Like in the kidnapping and extortion contexts, one who pays a piracy ransom does so out of fear or coercion. The person pays because the pirates threaten to harm hostages unless their demands are met. This is not a case of a person paying a bribe because of temptation or desire to improve his situation. Rather, it is the pirates who act out of temptation or desire to obtain illegal profits from holding innocent victims hostage. The person who pays the ransom took no part in the hijacking, and, instead, only learns about it after it has happened. While the payment may necessarily assist the pirates and help them continue their illegal activities, the payer is not making the payment with a criminal intent to assist in those unlawful activities. Nor is the payer receiving any portion of the illegal profits from the activities. Thus, as in the kidnapping and extortion contexts, one would expect that the criminal law would only seek retribution against the pirates seeking the ransom, as opposed to against the person who acceded to the pirates' demand unwillingly.

\section{B. Financing Terrorism}

We further analyze the question of whether a piracy ransom ban would be consistent with the criminal law's retributive aims by examining 18 U.S.C. \& 2339B, the provision of United States law that criminalizes providing "material support" for terrorism. ${ }^{167}$ We do so because like the laws examined above, Section 2339B also covers the situation where one makes a payment to another who is engaged in criminal activity. ${ }^{168}$ However, unlike with bribery-the one context previously discussed where the law would impose criminal liability on the payer ${ }^{169}$-one violates Section 2339B when he makes a payment, even without any corrupt or criminal intent. ${ }^{170}$ In this section, we ask whether punishing those who pay piracy

164. See id. at 1695 .

165. Id. at 1699 .

166. See, e.g., Elizabeth K. Spahn, Local Law Provisions Under the OECD Anti-Bribery Convention, 39 Syracuse J. INT'L L. \& CoM. 249, 274 (2012) (stating that payers who pay only in response to a threat to blow up an oil rig are acceding to extortionate demands, and are not liable for bribery, because criminal intent is absent).

167. 18 U.S.C. \& 2339B (2006) is a provision of the Antiterrorism and Effective Death Penalty Act of 1996 ("AEDPA"), Pub. L. No. 104-132, 110 Stat. 1214 (codified in relevant part at 18 U.S.C. $\S \S 2331-2339 D(2006))$.

168. 18 U.S.C. \& $2339 B$.

169. See supra text accompanying notes 144-145.

170. See U.S.C. \& 2339B. . 
ransoms could be justified on the same or similar grounds that have been used to justify punishing those who provide material support for terrorism.

18 U.S.C. § 2339B criminalizes knowingly providing "material support" to a foreign terrorist organization ("FTO"), or attempting or conspiring to do the same. ${ }^{171}$ The statute defines "material support" to include providing currency, monetary instruments, or financial securities." 172 FTOs should be understood as foreign organizations that engage in terrorist activities that threaten the security of the United States. ${ }^{173}$ An up-todate list of those who have been designated as FTOs is available on the U.S. State Department's website. ${ }^{174}$

The language of Section 2339B clearly criminalizes the act of making a payment. ${ }^{175}$ But does it require the payment be made voluntarily or with some intention to further criminal activity? The answer to this question is important because the analysis of how payers are treated in the context of kidnapping, extortion, and bribery thus far suggests that the criminal law ought only punish those who pay voluntarily with the actual intention of aiding or participating in the criminal activity. ${ }^{176}$ If Section 2339B criminalizes payments made under duress, then Section 2339B will run counter to our preceding analysis.

Both the language of Section 2339B, and the Supreme Court case law interpreting it, suggest that one need not intend to aid any criminal activity in order to be criminally liable for financing terrorism. ${ }^{177}$ By Section 2339B's plain language, one is guilty of financing terrorism as long as he has knowledge that the organization to whom he is giving money has been designated as a terrorist organization-whether or not he intends to further any terrorist activities. ${ }^{178}$

Additionally, the Supreme Court's recent decision in Holder v. Humanitarian Law Project supports a conclusion that only knowledge is required for a conviction under Section 2339B. ${ }^{179}$ In Humanitarian Law Project, plaintiffs challenged the constitutionality of Section 2339B's "material support" provision. ${ }^{180}$ The plaintiffs argued, among other things, that the provision violated their First Amendment rights of freedom of speech and association by failing to require the government to prove a specific intent to

171. Id.

172. 18 U.S.C. § 2339A(b)(1). See also 18 U.S.C. § 2339B(g)(4) (adopting the definition of "material support" found in Section 2339A).

173. See 18 U.S.C. \& $2339 \mathrm{~B}(\mathrm{~g})(6)$ (referring to Section 219 of the Immigration Nationality Act. Section 219 of the Immigration and Nationality Act is available at 8 U.S.C. $\S 1189$.).

174. See Bureau of Counterterrorism, Foreign Terrorist Organizations, U.S. Dep't Sт. (Sept. 28, 2012), http://www.state.gov/j/ct/rls/other/des/123085.htm.

175. See U.S.C. \& 2339B.

176. See discussion supra Part III.A.

177. 18 U.S.C. § 2339B; see also Holder v. Humanitarian Law Project, 561 U.S. 1, 17 (2010).

178. 18 U.S.C. \& 2339B

179. Humanitarian Law Project, 561 U.S. at 17.

180. Id. at 7 . 
further the unlawful ends of the designated FTOs. ${ }^{181}$ Plaintiffs stated that they only wanted to provide training and assistance to support the lawful and nonviolent activities of two groups which were on the FTO list-groups which had committed some terrorist attacks, but which also were working towards establishing independent states for the Kurds in Turkey and for the Tamils in Sri Lanka. ${ }^{182}$ The Supreme Court, however, concluded that the statute was constitutional as applied "to the particular activities plaintiffs [said] they wish[ed] to pursue." 183

Although it declined to "address the resolution of more difficult cases that may arise under the statute," 184 the Humanitarian Law Project Court did explain why Section 2339B did not violate the Constitution by requiring only knowledge, rather than intent. ${ }^{185}$ First, the Court noted that by the language of the statute, "Congress plainly spoke to the necessary mental state for a violation of $\S 2339 \mathrm{~B}$, and it chose knowledge about the organization's connection to terrorism, not specific intent to further the organization's terrorist activities." 186 It further noted that a review of the statute's legislative history showed that both Congress and the Executive Branch had determined that "providing material support to a designated foreign terrorist organization-even seemingly benign support-bolsters the terrorist activities of that organization."187 The Court echoed that determination when it stated:

Material support meant to promot[e] peaceable, lawful conduct . . . can further terrorism by foreign groups in multiple ways. Material support is a valuable resource by definition. Such support frees up other resources within the organization that may be put to violent ends. It also importantly helps lend legitimacy to foreign terrorist groups-legitimacy that makes it easier for those groups to persist, to recruit members, and to raise funds-all of which facilitate more terrorist attacks. ${ }^{188}$

However, the Supreme Court's decision in Humanitarian Law Project does not mean that Section 2339B would be constitutional if it was used to punish those who give money to terrorist organizations involuntarily. The Court confined its conclusion, that Section 2339B's "material support" provision does not require any intent to further the unlawful activities of the terrorist organization, to the facts before it. ${ }^{189}$ The facts in Humanitarian Law Project show that the individuals in that case intended to voluntarily give money to the organizations in question. ${ }^{190}$ They wanted to give

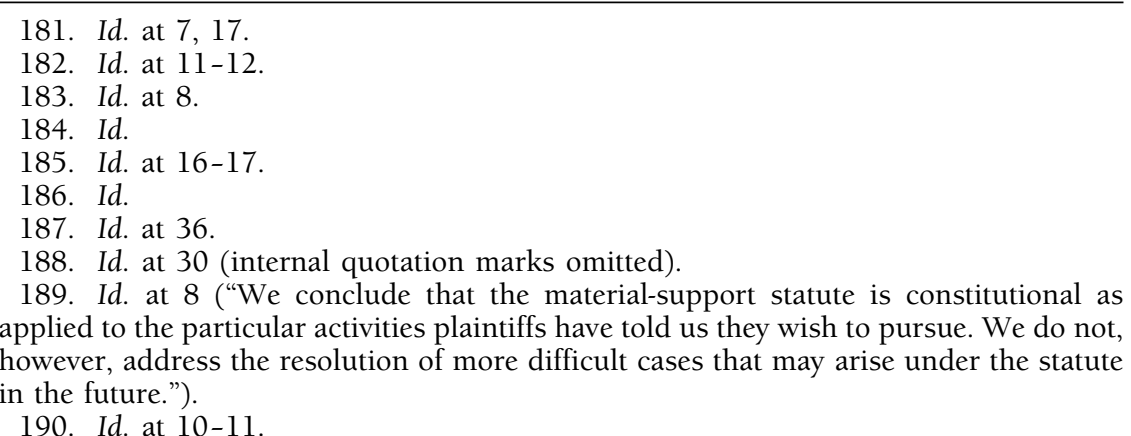
190. Id. at 10-11. 
money to organizations that they knew engaged in terrorist activities; they were not paying because of any threat or out of fear. ${ }^{191}$ Thus, the plaintiffs in Humanitarian Law Project would not be able to claim that they acted under duress such that they should be relieved of criminal liability. However, though the plaintiffs in Humanitarian Law Project did not intend to further the criminal activities of the terrorist organizations, they did make payments to further their own aims and desires. The Humanitarian Law Project plaintiffs are thus unlike the person who pays a ransom to a kidnapper or who pays in response to an extortionate demand. Those individuals pay out of fear because of a threat to make them worse off than they otherwise would have been. ${ }^{192}$ In both the kidnap and extortion situations, the individuals who pay would have had no interaction with the payee and the payees' criminal activities had they not been forced to pay in order to avoid having a threat carried out against them or against other innocent parties. ${ }^{193}$

In the absence of a decision precisely on point, we cannot unequivocally state that Section 2339B cannot constitutionally criminalize one who provides money to a terrorist organization only in response to a ransom demand. Research has not revealed any cases where the government is charging an individual with violating Section 2339B because he paid a ransom in order to save hostages from being harmed or killed at the hands of terrorists. Nevertheless, the analysis above does show that punishing those who make payments under duress would not be consistent with the criminal law's retributive principles.

\section{Analyzing the Practicality of a Piracy Ransom Ban}

In this section of the Article, we analyze the practicality of a piracy ransom ban by considering the unique international context in which maritime piracy occurs. Here, we examine whether, from an international law or collective action standpoint, there are reasons to believe that a state's individual decision to criminalize ransom payments would not provide an effective solution to the problem of maritime piracy. We conclude that absent a universal ban-which is probably unlikely-a piracy ransom ban will not deter pirates from continuing to hijack ships and holding their crews hostage.

Central to our analysis of the practicality of a piracy ransom ban is the ban's purported deterrence rationale. As discussed above, states with "no concessions" policies have resolved the ethical dilemma posed by a ransom ban in favor of the long-term goal of deterring future illegal activity, thereby protecting individuals from being held by pirates for ransom. ${ }^{194}$ Though these states accept that acceding to a ransom demand may save the lives of those individuals who are presently being held hostage, these states

191. See id. at 10-11.

192. See supra text accompanying notes 158-159.

193. See id.

194. See supra text accompanying notes 87-88. 
nevertheless favor a policy that they believe will protect more of their citizens from harm. ${ }^{195}$ Those favoring a piracy ransom ban advance this same deterrence rationale. ${ }^{196}$

However, we suggest that, when acting alone, a given state cannot hope to deter future acts of maritime piracy, thereby protecting its citizens from being future victims, by passing a law that forbids its citizens from acceding to pirates' ransom demands. We conclude as much because of the international context in which maritime piracy occurs. In the piracy context, one state's ransom ban may not inure to the benefit of that state's citizens because pirates will not likely know in advance the citizenship of the crewmembers of the ships they attack. Ships flying the flag of one state can include crewmembers from all over the world. ${ }^{197}$ The February 2011 capture of the Greek supertanker MV Irene 900 miles off the coast of Somalia illustrates this point. ${ }^{198}$ The twenty-five-member crew included seventeen Filipinos, seven Greeks, and one Georgian. ${ }^{199}$ In short, even if pirates may learn that certain countries have piracy ransom bans, such a ban will still not keep that states' citizens safe and off limits since pirates cannot tell the nationalities of a ship's crew simply by looking at the ship itself. Pirates may simply become more violent when they realize that they have captured a ship with laws forbidding the ship owner from paying a ransom.

Another practical issue arises from the fact that those who would be prohibited from paying ransoms are the ship owners, who may not share the same citizenship of the crewmembers who are held hostage. Filipinos comprise one-third of the world's sailors. ${ }^{200}$ Other large suppliers of seafarers include India, China, the Ukraine, Croatia, Latvia, Greece, Japan, Russia, and the United Kingdom. ${ }^{201}$ Of the hostages being held by pirates in 2012, a large number came from India (15\%), the Philippines (12\%) and China (7\%). ${ }^{202}$ As to ship owners, as of December 2010, the top 20 controlled merchant fleets in terms of gross tonnage were owned by parent companies located in the following states: Japan, Greece, Germany, China, the United States, the United Kingdom, Norway, the Republic of Korea,

195. See supra text accompanying notes 89-95.

196. See supra text accompanying notes 110-113.

197. See, e.g., Yvonne M. Dutton, Virtual Witness Confrontation in Criminal Cases: A Proposal to Use Videoconferencing Technology in Maritime Piracy Trials, 45 VAND. J. TRANSNAT'L L. 1283, 1319-20 (2012).

198. Id. at 1319.

199. Id. The ship, cargo, and crew were released two months later after the pirates were paid a $\$ 13.5$ million ransom. Id.

200. Filipino seafarers remain a top choice of Japanese ship owners, GMA NEws OnLINE (Oct. 28, 2008), http://www.gmanetwork.com/news/story/129907/pinoyabroad/fili pino-seafarers-remain-a-top-choice-of-japanese-ship-owners.

201. Numbers and Nationalities of World's Seafarers, Global Pacific, http://www.wel kin.ws/merchant-navy/shipping-industry/numbers-and-nationality-of-worlds-seafarers/ (last visited Feb. 18, 2014).

202. Kaija Hurlburt et. al., The Human Cost of Maritime Piracy 2012, at 4 (2013), available at http://oceansbeyondpiracy.org/sites/default/files/attachments/View\%20 Full\%20Report.pdf 
Denmark, Hong Kong, Taiwan, Singapore, Italy, Russia, Canada, Turkey, Malaysia, India, France, and Belgium. ${ }^{203}$ A situation could arise where a ship's owner and a ship's crew are from various countries, some of which have banned ransom payments, and some of which have not. In such a situation, the citizens of multiple countries could suffer as a result of one country's ban on ransom payments.

The fact that a handful of states supply most of the world's seafarers is one reason why getting states to agree on a universal ban against paying piracy ransoms is unlikely. There is a collective action problem where refusing to negotiate may be in the interests of the world community as a whole, but paying a ransom may be in the interest of some states or some individuals. Why would these states from which most crewmembers hail agree to ban piracy ransoms when their citizens would so disproportionately suffer from the imposition of such a ban? Would these states willingly sacrifice their own citizens' lives in the short term, even if the long term result would be that pirates would be deterred more generally from engaging in future hijackings? Could these states ethically justify requiring their citizens to choose to sacrifice the safety of a person being held for ransom, so as to deter future pirate attacks? We suggest that unless all states agree to a piracy ransom ban, including the states from which most crewmembers hail, there is little hope that pirates will be deterred from continuing to hijack ships in the hopes of receiving huge ransoms for the release of ships' crews. States cannot send a message to pirates that hijacking ships will not pay unless all states and ship owners are equally constrained from meeting pirates' demands.

One way to mitigate this problem of risking the lives of one state's citizens as the result of another state's piracy ransom ban would be for the state with the ban to agree to use military force to rescue the hostages. Yet this solution comes with its own set of potentially insurmountable international law and collective action issues. Different states may have seemingly greater or lesser interests in deploying their military forces to free hostages. States may also have greater or lesser abilities in this regard. Some states may want their citizens to be rescued, but they may not have the military might to accomplish such a rescue safely. On the other hand, all rescue efforts can be risky, even for the hostages who are to be rescued. Some states may not want their citizens exposed to those risks, even if the state imposing the piracy ransom ban is willing to attempt a rescue. Furthermore, a military rescue could be problematic and could be opposed by some states where a ship's cargo (oil, chemicals, etc.) could damage the environment if the ship is damaged during a rescue attempt.This begs the question: should seafarers on ships with certain kinds of cargo be entitled to less protection than others?

203. Int'l Mar. Org., International Shipping Facts and Figures - Information Resources on Trade, Safety, Security, Environment \& 3.7, MAr. Knowledge CTr. (2012), available at http://www.imo.org/KnowledgeCentre/ShipsAndShippingFactsAndFigures/TheRole andImportanceoflnternationalShipping/Documents/International\%20Shipping\%20-\% 20Facts\%20and\%20Figures.pdf. 
Even if states supplying the world's crewmembers did not object to individual state ransom bans, or were willing to implement such bans, obtaining a universal piracy ransom ban is still unlikely. Because ship owners do not favor a ban, ${ }^{204}$ both flag states and home states of ship owners have financial and other incentives to refuse to ban piracy ransoms. The bottom line is that ship owners will want to pay for the release of their cargo and crews, even if it means that by doing so they are necessarily fueling maritime piracy. Many ship owners might feel moral or religious obligations to save their crews from harm. ${ }^{205}$ They may also come under public pressure to pay so that innocent lives are spared. ${ }^{206}$ In addition, the cost of purchasing kidnap and ransom insurance, and the cost of a multimillion dollar ransom payment, ${ }^{207}$ pale in comparison to the monies ship owners lose when their ships are detained for months or even years by pirates: a typical hijacking of a cargo ship in 2011 cost the ship owner around $\$ 9$ million in unrealized charter rates alone. ${ }^{208}$

To explain why flag states and home states will want to embrace the views of ship owners and refuse to ban piracy ransoms, we focus on open registries, known as a "flags of convenience," and also on the nature of the global economy. Our conclusion is that there is a clear incentive structure militating strongly against the universal, nearly simultaneous piracy ransom ban that would be required to achieve the stated goal of deterrence. While banning piracy ransoms may be good for the world community as a whole because it has the promise of stopping pirates from hijacking ships, a collective action problem arises whereby some states or individuals will view paying ransoms to be more individually beneficial in the short run.

First, because of the open registry market, ship owners may choose to locate and register their ships in a state that does not ban them from pay-

204. See supra text accompanying notes 114-119.

205. Lansing \& Petersen, supra note 84 , at $512-13$ (noting that ship owners may pay ransoms for religious reasons, but also may pay so as not to "have blood on their hands'" or feel responsible for the death of another).

206. In both the MV Iceberg and MV Leopard cases, slanted coverage of the fate of the two ships and the lack of effort taken to rescue their respective crews continued even two years after the ships were initially captured. See, e.g., Priyanka Dube and Shoaib Ahmed, MV Iceberg: 2 years on, Govt yet to take action, CBB-IBN (Mar. 30, 2012), http:// ibnlive.in.com/news/mv-iceberg-2-years-on-govt-yet-to-take-action/243978-3.html

("Abandoned by the ship owner, tortured by the pirates and forgotten by the Indian government, the sailors [aboard the MV Iceberg] are the longest-held hostages in Somalia"; see also Fate of the crew of $\mathrm{m} / \mathrm{v}$ Leopard is unclear with owner's insolvency, MAR. Bulletin (Oct. 14, 2011), http://www.odin.tc/news/print.asp?articleID=58. But see Kaija Hurlburt et. al., The Human Cost of Somali Piracy 28 (2011), available at http:// oceansbeyondpiracy.org/sites/default/files/human_cost_of_somali_piracy.pdf (establishing that the human cost of piracy is still underreported and misunderstood by the public).

207. ECOP 2012 supra note 16, at 10, 33 (listing typical insurance kidnap and ransom insurance rates as ranging from $\$ 7,500$ to $\$ 12,500$, and listing $\$ 3.97$ million as an average ransom payment).

208. See James Kraska, Freakonomics of Maritime Piracy, 16 Brown J. World AfF., Spring/Summer 2010, at 114 ("A typical [cargo] vessel charter rate is $\$ 50,000$ per day ...."); ECOP 2011, supra note 37, at 11 (reporting that the average duration of a pirate hostage taking in 2011 was 6 months). 
ing piracy ransoms. Registering a vessel in an open registry state is not an onerous process, sometimes requiring little more than the ship owner completing a registration form in order to fly the flag of another state. ${ }^{209}$ Forum shopping through ship registries can be traced back to English merchants sailing under the Spanish flag in the sixteenth century to evade English trade regulations. ${ }^{210}$ Similarly, the contemporary, widespread use of flags of convenience is seen primarily as a tool for ship owners to forum shop for favorable taxation and regulatory provisions. ${ }^{211}$ In turn, open registry states treat their ship registries as profit-making entities, and the fear of losing income to states with more ship owner-friendly regulatory regimes creates a clear incentive for states to cater to the needs and desires of ship owners, which at present requires, among other things, allowing ransom payments to pirates. ${ }^{212}$

Moreover, these registries are often significantly economically important to the countries operating them. Take, for example, LISCR, LLC, a Virginia-based limited liability corporation that acts as Liberia's national registry. 213 According to the United States Department of State, Liberia's "revenues come primarily from rubber exports and revenues from its maritime registry program." 214 In 2004, the last year the LISCR was audited, its gross revenues were $\$ 36$ million, ${ }^{215}$ which, as of 2011, would compose almost 3\% of Liberia's entire GDP. ${ }^{216}$ In 2007, LISCR's revenue accounted for a full $6 \%$ of the government of Liberia's total operating budget. ${ }^{217}$ Given that ship registration generates an important, if not essential, revenue stream for some states by catering to the interests of ship owners,

209. What are Flags of Convenience?, InT'L Transp. WORKERS' Fed'N, http://www.itfglobal.org/flags-convenience/sub-page.cfm (last visited Feb. 18, 2014) ("Cheap registration fees, low or no taxes and freedom to employ cheap labour are the motivating factors behind a shipowner's decision to 'flag out."'); Jessica K. Ferrell, Comment, Controlling Flags of Convenience: One Measure to Stop Overfishing of Collapsing Fish Stocks, 35 Envtl. L. 323, 336 (2005) ("Generally, a vessel's flag is considered [a flag of convenience] if the only link between the flag state and the ship is registration-as opposed to management, crew, nationality, ownership, or any other "genuine" connection with the state.").

210. Boleslaw Adam Boczek, Flags of Convenience 6 (1962).

211. R. Tali Epstein, Note, Should the Fair Labor Standards Act Enjoy Extraterritorial Application?: A Look at the Unique Case of Flags of Convenience, 13 U. PA. J. INT'L Bus. L. 653, 666 (1993).

212. Paul T. Hinckley, Raising The Spector of Discrimination: The Case for Disregarding "Flags of Convenience" in the Application of U.S. Anti-Discrimination Laws to Cruise Ships, 3 Mod. Aм., Summer-Fall 2007, at 76 (describing the "race to the bottom" created by countries' open ship registry systems).

213. Company Overview of LISCR, LLC, Bloomberg Businessweek, http://investing.businessweek.com/research/stocks/private/snapshot.asp?privcapid= 6530292 (last visited Oct. 29, 2013); see also Liberian CorPorate Registry, http://liberiancorporations .com/ (follow "CONTACT US" hyperlink) (last visited Feb. 18, 2014).

214. Bureau of African Affairs, U.S. Relations with Liberia, U.S. Dep't St. (July 26, 2013), http://www.state.gov/r/pa/ei/bgn/6618.htm.

215. Adam Shaw, Liberia: A New, Assertive Bureau of Maritime Affairs, WikiLeaks, II 8 (Jan. 21, 2009), http://wikileaks.org/cable/2009/01/09MONROVIA70.html.

216. See Liberia Country Report, Global FIn., http://www.gfmag.com/gdp-data-coun try-reports/233-liberia-gdp-country-report.html\#axzz2j3WNn7fb (last visited Oct. 29, 2013).

217. Shaw, supra note 215 , TI 8. 
states dependent on such revenue streams have a substantial interest in not instituting a ransom ban.

The nature of the globalized economy provides a second reason why states are unlikely to ban ransoms. There is such a diversity of corporate advantages and disadvantages, depending on which state a business operates in, that any business owner, ship owner or otherwise, can move his business to the state where he will be afforded the most advantage. To illustrate the ease with which modern multi-national corporations can use regulatory diversity to their advantage, consider the example of multinationals transferring their profits out of the United States to low-tax jurisdictions such as Ireland. Economist Martin Sullivan explained the process as follows in testimony to the United States House Ways and Means Committee:

Suppose a U.S. multinational has a foreign manufacturing and distribution subsidiary in Ireland. Suppose that for a nominal fee the U.S. parent company allows the Irish subsidiary to use valuable marketing and manufacturing intangibles. Without access to these intangible [sic] the Irish subsidiary would only have $\$ 100$ of profits. $\$ 100$ is the true economic income attributable to the activities in Ireland. Access to the parent company's intangibles allows the Irish subsidiary to book $\$ 300$ of profit. The Irish subsidiary should be paying the U.S. parent $\$ 200$ in royalties (or its equivalent) but because of lax transfer pricing rules it does not.

The corporate tax rate in Ireland is $\mathbf{1 2 . 5}$ percent, so Irish tax liability in this example is $\$ 37.50$. The shift of $\$ 200$ of profits out of the United States reduces U.S. taxes by $\$ 70$. The total net tax on the Irish investment is minus $\$ 32.50$ on $\$ 100$ of economic income. The effective tax rate is negative 32.5 percent. This is far below the 35-percent rate paid by purely domestic U.S. corporations on their profits and far below what Irish corporations pay on income from their domestic operations. ${ }^{218}$

In other words, because the United States treats subsidiary companies as unrelated to the parent, and because of the difficulty of placing an accurate valuation on intangible assets such as patents, multi-national enterprises are able to achieve low, sometimes negative effective tax rates. This is particularly the case in industries that rely heavily on intangible assets, such as the pharmaceutical industry, where the seven largest companies saw an increase of 361\% in foreign profits between 1997 and 2007, with a corresponding $80 \%$ decrease in domestic profits. ${ }^{219}$ These changes in profit allocation did not correspond to changes in actual business practices. ${ }^{220}$ They are almost entirely attributable to multi-nationals' legally compliant tax planning, which takes advantage of regulatory diversity to

218. Testimony of Martin A. Sullivan on Transfer Pricing Issues in the Global Economy: Hearing before the Committee on Ways and Means, U.S. House of Representatives, 112th Cong. 6 (July 22, 2010), available at http://waysandmeans.house.gov/media/pdf/111/ 2010jul22_sullivan_testimony.pdf.

219. See id. at 3.

220. See Martin A. Sullivan, Drug Company Profits Shift Out of United States, Tax Notes, 1163-66 (Mar. 8, 2010), http://www.bradreese.com/blog/3-8-2010.pdf. 
help the bottom line. ${ }^{221}$

It is easy to imagine a similar "regulatory arbitrage" occurring in the shipping industry in the case of a piracy ransom ban. Imagine the United States passes a law banning any American ship owner from paying a ransom to pirates. In this hypothetical, the nearby Bahamas has no such ransom ban. The American ship owner can avoid the United States ban by creating a Bahamian subsidiary, wholly owned by the American parent company, in order to pay the ransom. This easily executed tactic to avoid one state's ransom ban suggests that any single ransom ban may have little hope of achieving the desired deterrent effect. Additionally, one state's decision to implement a ransom ban could cause it to lose revenues from businesses that relocate to other states. It is the equivalent of economic unilateral disarmament. To be sure, some countries would place their sense of moral and ethical obligation to deter piracy above the economic disincentive. But the fact remains that as long as it is possible to imagine one country that chooses to place economics above morals, it remains impossible to imagine a piracy ransom ban that functions as desired.

Finally, even if ship owners decide to remain in states that criminalize piracy ransoms, policing ship owners to ensure they do not pay a piracy ransom could prove very difficult. Trying to police against ship owners purchasing kidnap and ransom insurance could also prove difficult. The collective action problem is again at play. Ship owners will not likely take kindly to any ransom ban unless it applies to all ship owners, since they will otherwise believe they suffer an unfair disadvantage as compared to ship owners who are not legally prohibited from paying ransoms. As a result, all states would need to be committed to enforcement and to devoting resources to monitoring ship owner activities. However, not all states have the same financial resources or law enforcement capabilities. Accordingly, to ensure that any piracy ransom ban is effective, all states would have to be committed to legislating it and committed to enforcing it. States would also likely have to be willing to monitor one another in order for a ban to have any hope of producing its desired deterrent effect.

\section{Conclusion}

In sum, the legal and practical issues surrounding any potential ban on piracy ransom payments are substantial. Legally, a ban is likely inconsistent with the retributive principles of the criminal law, because such a ban would punish those who pay money to pirates under duress without any actual intent to further criminal activity. Further, from an international law standpoint, banning piracy ransoms would be impractical because any such ban would pose collective action problems. Our analysis suggests that states should not even continue to consider a piracy ransom ban unless they are prepared to act in a coordinated fashion. States have little or no hope of deterring maritime piracy unless all states are prepared 
to criminalize the payment of ransoms to pirates. One state's ban is not only unlikely to have a general deterrent effect, but it is also unlikely to protect its own citizens from being taken hostage. Without total cooperation, a piracy ransom ban could put innocent lives at risk without providing deterrence.

Absent a universal ban, governments, of course, can proceed with the status quo and permit individuals to pay ransoms to pirates without any risk of being criminally sanctioned. Governments can also explore other ways to facilitate deterring acts of maritime piracy. For example, governments could become more involved in ransom negotiations. This is not to say that governments should pay ransoms directly. But if national law enforcement agencies were more deeply involved in the negotiation process, they may be able to more effectively gather information that could be used to prosecute the financiers and enablers of piracy, an oft-stated goal of the international community.222 If those "larger fish" are captured and prosecuted, the result may be that some pirate gangs are deprived of their leaders or the funds they need to stage attacks, thereby deterring some acts of piracy.

No path forward may offer a perfect solution, which we define as one that puts an end to maritime piracy and makes the high seas safe for those who transit through them. We are sympathetic to the need to find a solution to the problem of maritime piracy and the piracy ransoms that help fuel the illegal activity which threatens the lives of innocent seafarers. However, we urge states to fully consider all of the legal and practical issues associated with a piracy ransom ban before advancing a ban as the solution to what is a very complicated problem. We also urge states to work together to seek coordinated and universal solutions. Our hope is that by analyzing and addressing those issues here, we have helped encourage deep, meaningful and inclusive policy discussions.

222. See, e.g., 2013 World Bank Report, supra note 14, at 179. 
